\title{
Evolution of the urban form in the British new towns
}

\author{
Julia Deltoro Soto, Carmen Blasco Sánchez, Francisco Martínez Pérez
}

Escuela Técnica Superior de Arquitectura. Universitat Politècnica de València. Valencia, Spain E-mail: judelso@cst.upv.es, mblasco@urb.upv.es, fjmartpe@urb.upv.es

\begin{abstract}
Even if the urban experience of the British New Towns, created after the New Towns Act of 1945 as a solution to the problems derived from the superpopulation of great cities such as London, is already far in time it can still offer us some lessons. Lessons which could help us when intervening in current process of development and transformation of the urban form. This article analyses these experiences from its morphology, studying their formal characteristics and the organization of the several uses of the city, as well as the diachronic evolution of their criteria of spatial composition. Their urban forms evolved with time and were the result of many strategic and design decisions taken which determined and transformed their spatial and physical profiles. The analysis of the essential characteristics and strategies of each of the phases of the New Towns, applied to the configuration of the urban form of some of the New Towns, the ones which gather better the approach in each of the phases, will allow us to make a propositional diagnose of their different forms of development, the advances and setbacks; a comparative analysis of different aspects such as mobility and zoning, local and territorial relations, structure or composition. The conclusions of the article pretend to recognize the contributions, which come from their urban form and have them as a reference for new urban interventions in the current context, with new challenges to be faced from the integral definition of the city.
\end{abstract}

Keywords: New Towns, Morphology, Britain, Urban Form, Urban

Structure.

\section{Introduction}

"New Towns are cities or towns that are designed from scratch and built in a short period of time. They are designed by professionals according to a Master Plan on a site where there was no city before. This distinguishes a New Town from a 'normal' city that gradually grows and evolves over time. Also, New Towns are mostly the result of a political (top-down) decision. The building of a new city 'from scratch' is a heroic enterprise that challenges the architect or planner to find the ideal shape for the urban program according to the state of the art planning ideas. A New Town is always a reflection of one moment in time and the ambitions of that moment."
This definition of the New Towns by the International New Towns Institute (INTI) shows the importance of the Master Plan and the search for the ideal shape for it according to the planning ideas of their moment of creation. The ones studied in this paper are defined in the glossary of the New Towns Record (Burton \& Hartley, 2003) as the ones developed after the New Towns Act of 1946 and subsequent amendments, and to a comprehensive town plan. These were created as a solution to the problems derived from the superpopulation of big cities such as London, and their physical and spatial characteristics were the result of a series of strategical and design decisions. These experiences essayed new urban models which were later taken as an example by other countries for the development of their new 
cities following similar objectives, as in France or Nordic countries.

Despite being distant in time, this urban experience can still offer lessons and reflections when intervening in the transformation and development of the urban form. The work carried out in the New Towns gather experiences in different urban and territorial contexts and has offered a different answer in each situation, from the more suburban proposals to the creation of new cities, through the reform of consolidated and degraded fabrics.

This paper analyses them from the point of view of their urban form, studying the formal characteristics, the organization of the different uses within the city, as well as the diachronic evolution of their spatial composition criteria.

The first New Towns built mainly followed the characteristics stated in the Reith Report

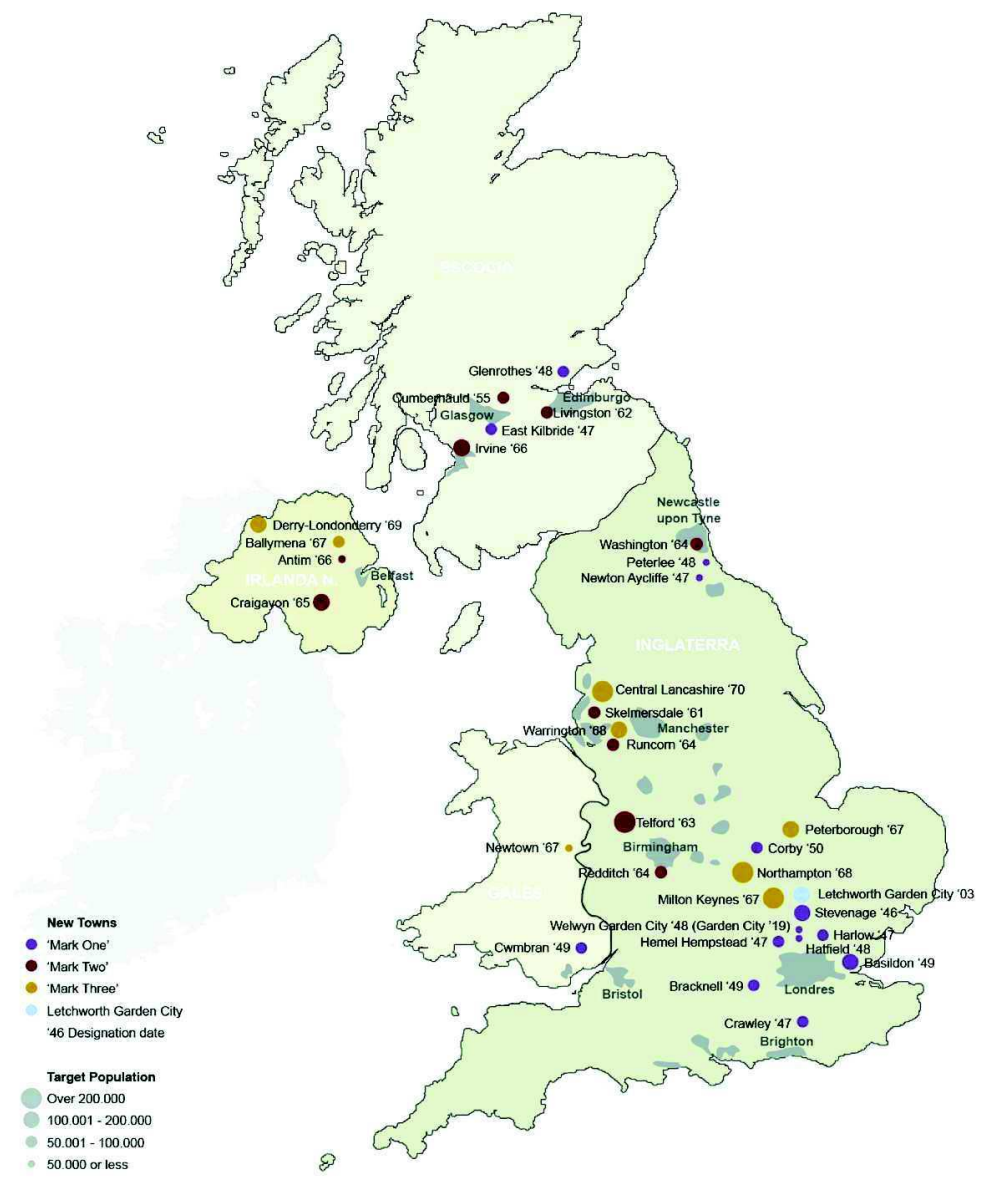

Figure 1.

Location, size, designation date and British New Towns classification. Source: own elaboration from data extracted from the images found in (TCPA, (Town and Country Planning Association), 2014).
(HMSO, 1946 a) and in the later New Towns Act (HMSO, 1946 b). The scale of the new cities, the location, the uses and zoning criteria (urban centres, residential units, industry and work centres, education, green areas and transportation networks), areas and the distances of and between the different uses, the social structure or the treatment of the landscape, among other aspects were defined in them.

However, the urban form of the New Towns, developed between 1945 and 1970, evolved over time, incorporating new aspects and concepts resulting from research carried out in parallel got adapted to the particular context of each one of them, correcting errors and introducing elements which would transform their urban shape, such as new forms of mobility. The critical analysis of the previous experiences was established also as an unavoidable process before the formulation of new developments.

According to the Town and Country Planning Association (TCPA, 2014) the New Towns can be classified into three Marks or generations according to their chronology and the laws that allowed to create them.

The New Towns of Mark I (1946-1950), which include fourteen New Towns designated between 1946-50, had a population from 20,000 to 60,000 inhabitants. Eight of them, Stevenage, Crawley, Harlow, Hemel Hempstead, Welwyn, Hatfield, Basildon and Bracknell, were located beyond the London Green Belt and followed Abercrombie's recommendations of the Greater London Plan and the Reith Report.

This first generation of towns inherited the initial idea of Howard's Garden Cities, though not in the concept of social cities, which was 
not reflected in the Reith Report. Although they were also conceptually distant in some respects, they were slightly larger than Howard's ideal size (32,000 inhabitants), and were based more on the need for new housing than on the community organization of the new inhabitants.

These cities had to be balanced, selfsufficient, with a heterogeneous population and a provision for employment, housing and the necessary facilities and open spaces. Had to be located at about $40 \mathrm{~km}$ from London and $20 \mathrm{~km}$ from other metropolis, so that they could achieve a minimum trip duration to the capital city, thus contributing to the planned decentralization of it.

The urban structure is marked by a very strict zoning, the uses are distributed almost unmixed. Two main centres can be distinguished, the industrial and the urban centre, connected by the rail and the main roads that communicate it with other cities. Around these cores the residential units are distributed, and the free space available between the mentioned uses, both interior and exterior, is occupied by green space. The layout and relationships between the elements of the city and the centre were determined by foot distances.

The centre of the city, were the offices and most commercial services are located, is
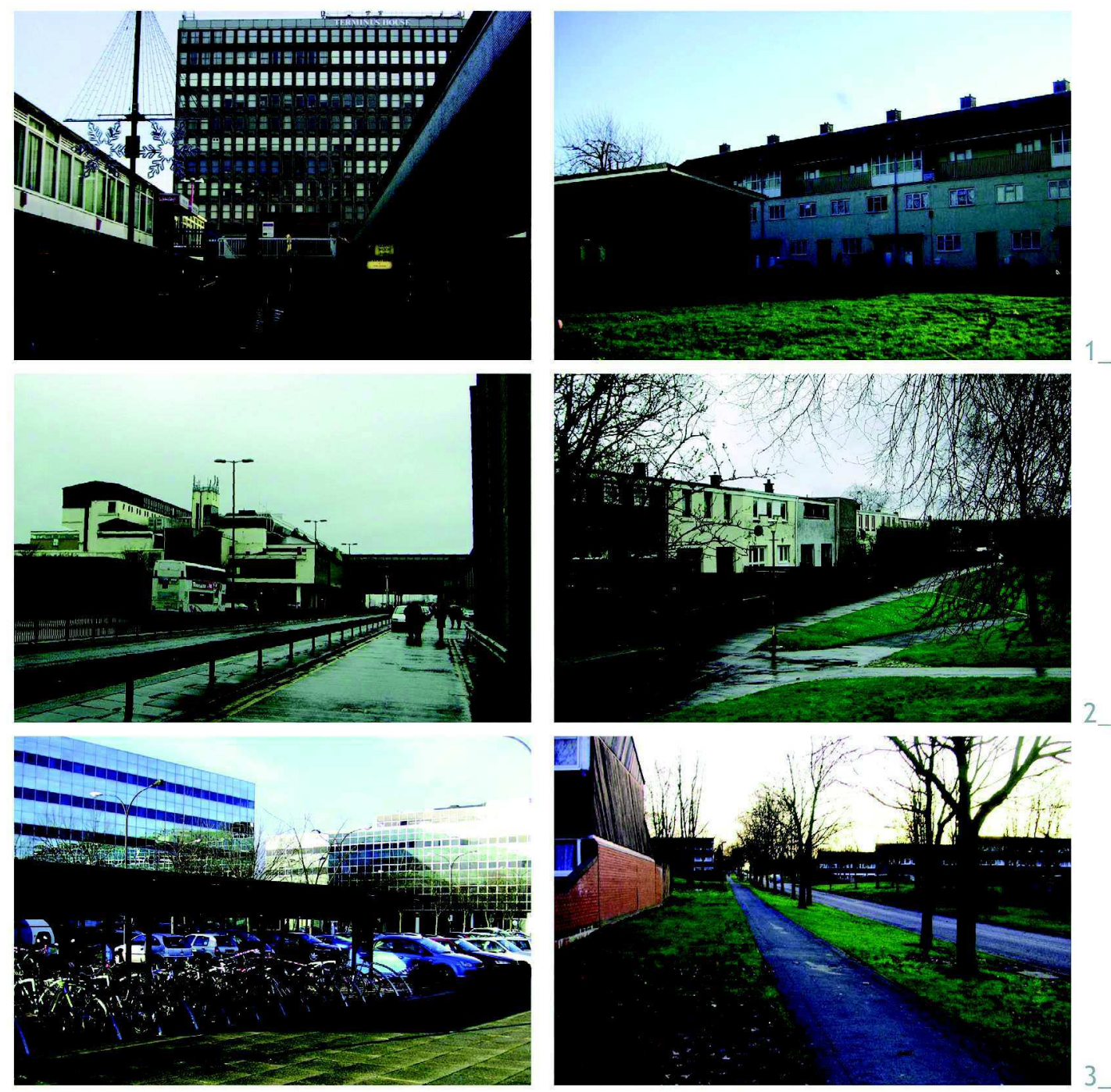

Figure 2.

Images of the urban centre and residential areas 1_Harlow, 2_Cumbernauld, 3_Milton Keynes. Source: photos of the authors. 
normally placed in the geographic centre of the territory to be occupied. It is pedestrian and protected from the passing traffic, and where the pedestrian paths converge a large central square is located with elements such as a clock tower or other unique buildings to emphasize its importance, giving it the necessary centrality and representativeness.

Regarding the road system, in the interior of the city there was almost no hierarchical differentiation, although the functional separation of road and pedestrian traffic is considered. The neighbourhood units are separated by traffic routes that connect them to the urban centre, but without crossing it.

Being considered industrial cities, the industry dominates the structure of the city and is located in strategic places, adjacent to the railroad and to the main road accesses, inside the limits of the city.

Residential units are designed in detail creating more or less compact clusters, based on the concept of the Neighbourhood Unit coined by Clarence Perry. Each one of them owns its communal centre with stores, a church and school that, in general, are in the centre of the neighbourhood unit, with a pedestrian access. These are used to divide the city into recognizable parts, to achieve it the units are related to each other by green spaces. The number of neighbourhood units varies between three and ten, and the population of each of them between 3,000 and 10,000 inhabitants, and with a density of 75 people per hectare.

The building typology follows the English tradition, with two-level houses either in rows or paired, with private gardens and served by a Radburn type road system, that separates the roads and culs-de-sac from the pedestrian areas. This was the type of housing that everyone who had suffered from the lack of space in the overcrowded suburbs of the beginning of the century wanted to have in the New Towns, although some buildings were also built in height, as it will be seen later.

The green areas, with large parks and field extensions is the background on which the rest of the functions of the city are located and developed, or in other words, the base that complements the spaces between the different parts of the built city. Green areas connect the pieces of the city, emphasizing the contrast between the urban elements and the territory. Vegetation is concentrated or dispersed in small areas throughout residential areas. These areas are also considered as a space for future expansion and a way of preserving the surrounding landscape. The design of the landscape, as it could not be otherwise, assumes the tradition of the English School.

The New Towns of Mark II (1951-1966) are of a greater size and located at a greater distance from the metropolis, in the case that its objective of creation is to cause the decongestion of the main city, as some of them were expansion of existing towns. Among other this Mark includes, Cumbernauld, Livingston, Telford, Washington or Irvine.

They are more compact, in their urban structure, of higher densities and the separation by uses is less rigid. These New Towns took into consideration the increase of vehicles used by its population and the previous problems of the congestion of the cities, which led to changes in the design of its structure. For this reason, the city adopts a linear shape.

A very compact urban centre predominates in the middle of the city, with separate traffic, the parking is located below the centre to avoid it being surrounded by traffic. It can be reached on foot from any point of the city, so now all residents will go to a single centre. It accumulates more commercial facilities and services, giving it more importance so its capable of generating more activity and making the city look like a single entity, something which was criticised in the previous towns. The idea of creating local centres in different neighbourhood units is abandoned,

The road system was designed with a higher hierarchy, following the ideas of Le Corbusier, Alker Tripp and Abercrombie. The separation of traffics is even greater than in its predecessors. The principle of the separation of traffic is performed at different heights, and was applied to the whole city and not only to residential units. The design was made considering the pedestrian and private traffic, not so much the public transport, as it did not need a sophisticated provision due to the compactness of the cities. 
The industrial areas got dispersed around the city occupying smaller surfaces, although were associated in the same way to the roads of a greater importance.

The concept of self-sufficient neighbourhood units is set aside, and a compact residential continuum is built, with a density in Cumbernauld of 205 inhabitants per hectare. Some houses are incorporated in the centre of the city, mixing its uses.

The architecture used a more modern language than the previous New Towns. The green spaces, as the city was more compact were concentrated in the limits of it, conforming a green belt.

Finally, the ones of the Mark III (1967-1970), including as Milton Keynes, Northampton or central Lancashire, with a proposed population of 250,000 up to inhabitants, are distinguished by the existence of large pre-existences which influenced their forms and locations (MadaniPour, 1993). The general characteristics presented in them could be summarized in the following points.

Regarding the urban structure, the rigidity in the uses present in the first generation was relaxed by the need for flexibility, a physical structure for the development of the city was designed, so that it could be modified according to future needs. The increase in the number of vehicles coupled with an increase in population in these New Towns played a determining role in their urban form. It is attempted to create a non-hierarchical and homogeneous city; a road grid was established and some fixed elements were arranged in it.

The centre of the city is dominant and several dispersed sub-centres are associated with of the units or districts and are located at their boundaries. When a city already existed, the centre was situated in it or adjacent, completing the existing centres.

Mobility remains a central issue, New Towns, rather than being independent entities, need to be integrated into their region. For the road system, new concepts of networks and possible hierarchies of the roads are studied. A clear and strict hierarchy of the road, primary, secondary and local networks of access to housing is created. Isolated superblocks are created along the road and the segregation of conventional, pedestrian and car traffic with public transport is produced. Due to the change of scale in the size of the settlement and its population, the different parts of the city are connected by means of a fast transport, and are no longer designed according to the distances on foot.

In some New Towns, the public transport is the generator of a more linear urban form and this type of transport becomes more important. This is adapted to the pre-existences and topography of the designated area taking the form of an eight (Runcorn), circular, linear (Redditch) or grid (Washington) shapes to

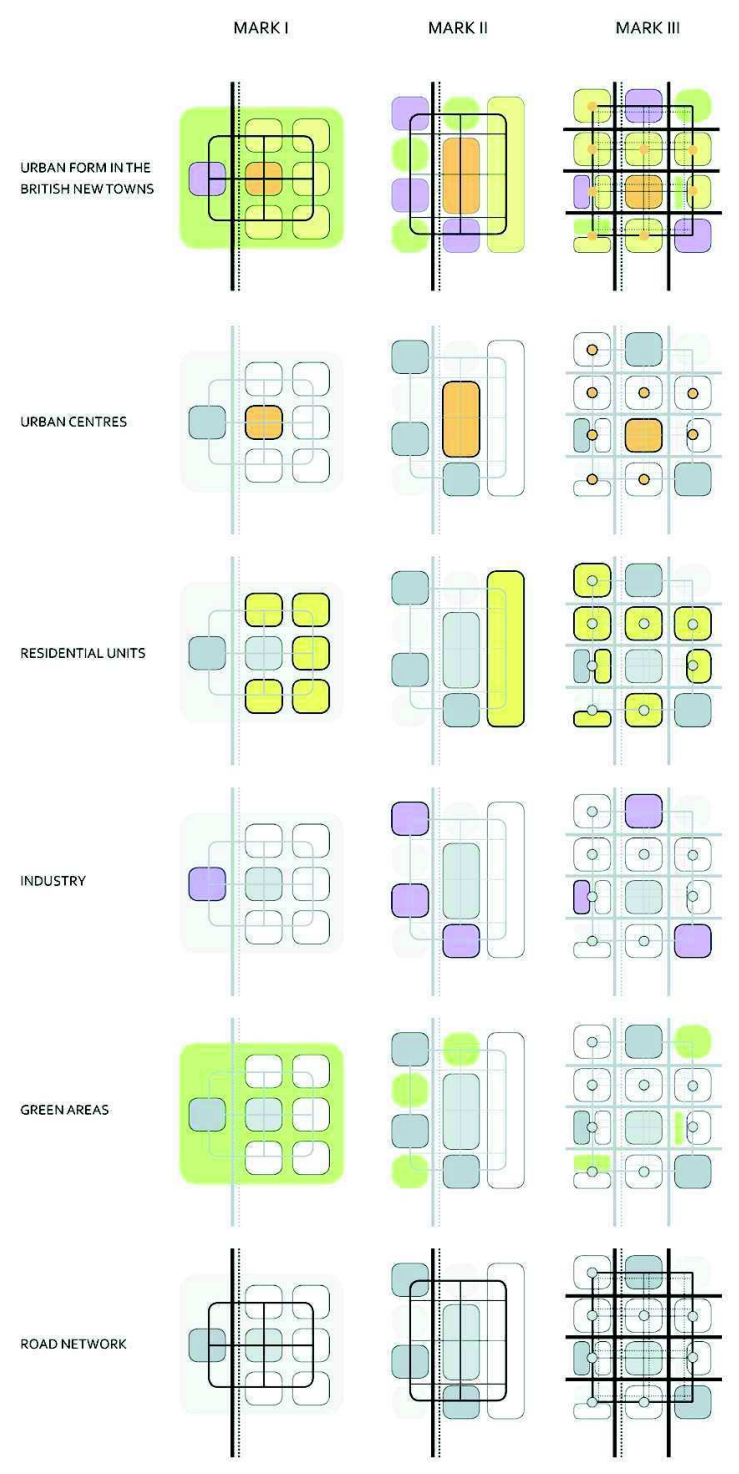

Figure 3.

Schemes showing the evolution of their forms and distribution of uses in the New Towns. Source: own elaboration. 


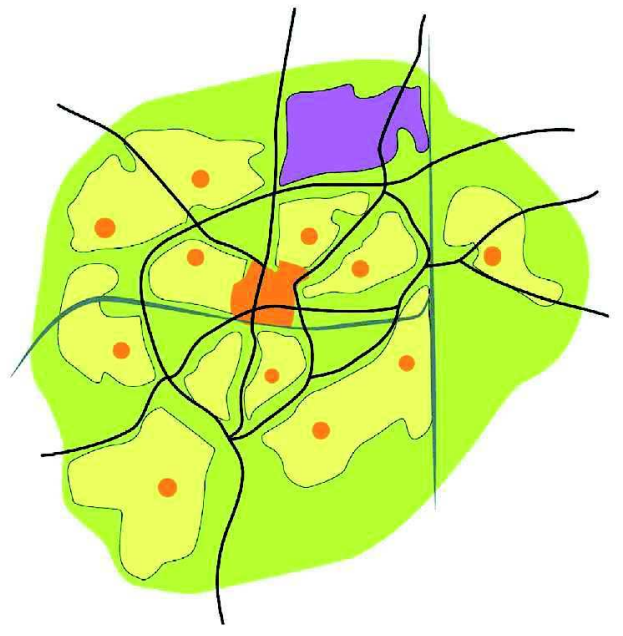

1

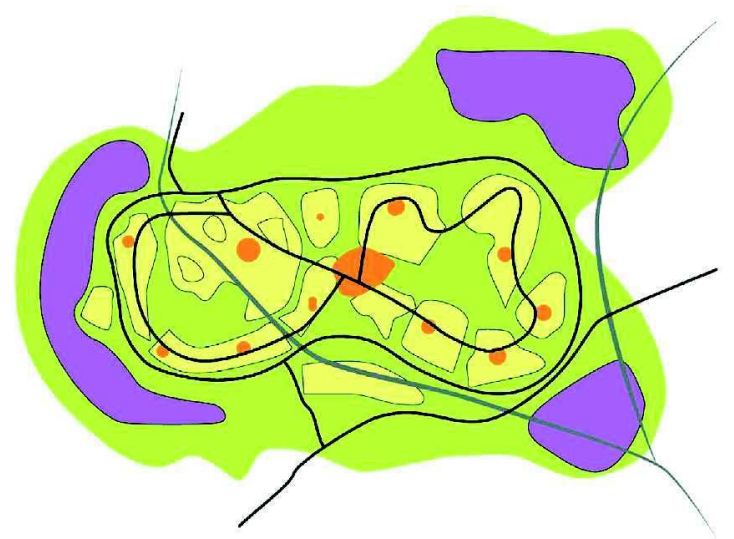

3.

Figure 4.

Schemes of New Towns representative of each of the four phases.

Phase 1: Crawley. Phase 2: Cumbernauld. Phase 3: Runcorn. Phase 4: Washington. Source: own elaboration from the plans of the towns.

connect the residential areas with the centre. There is a lot of importance to private transport and to try to connect all the points of the city in an efficient and fast way. The transportation stops of the superblocks are the focus of the area that surrounds them and are accessed by foot, by car or taxi. Districts are distributed around these, so that they are accessible from all points on foot.

Later, the form of the road network adopted by several cities was the grid, allowing a better connection between the points of the city, as they are larger and with a larger population. It aims to obtain an equivalent accessibility from all the parts of the city and give its inhabitants the same options. The areas created to withstand heavier traffic, as industries, were scattered throughout the city and usually located near the nodes of activity. This was possible since the type of industry was less polluting than in previous times.

Residential areas are grouped into separate units or districts of limited size, which divide the city into different residential areas that can be independently constructed at each stage of development. Each one becomes an urban entity in relation to the others in a linear way, in response to the greater need for accessibility 
in both public and private transport. It tries to find the minimum element, the residential unit which can be repeated and constitute the city is by the sum of them. Each unit consists of several housing groups.

Radburn's idea is applied to the superblocks, the result is still similar to that of Clarence Perry but the facilities are not located in the centre but in the limits of the neighbourhood and associated with public transport stops.

The size of each unit is determined by on foot distances and by local facilities. The maximum walking distance is about 500 meters, 5 to 7 minutes' walk. Public transport stops are located every 800 meters. The population of the units created depends on the desired capacity for the primary school, varying between 2,000 and 4,000 inhabitants. The density also varies depending on the location of the unit, denser if it is closer to the bus stop and less dense if it is further away, as it is accessed by car.

However, this is not the only classification recognized among specialized literature. If we focus on their morphology, we can classify them according to criteria focused on the urban form and less on the legislation that gives them official support. Thus, based on the classification made by Ali MadaniPour (1993), we can distinguish four phases of development and design that cater to the different social and mobility needs during the 25 years of interventions.

The first opted for an isolated city, distributed in a radial way, with an urban centre located in the geometric centre of the city and the industrial areas located near the railway. The residential areas followed the characteristics of the Neighbourhood Units and the local centres were in the middle of the unit. Green areas have a great presence and connect the different uses. New communities are taken care of and many green and open spaces are offered, in contrast with the dense and overpopulated cities from which they came. Two examples would be Harlow or Crawley.

The second phase, which includes cities with larger population and size, takes a more linear form given the increased use of the vehicle and changes in mobility, its residential areas are compacted in response to the criticisms received in the first New Towns. Urban spaces and the non-built or green spaces contrast clearly. Urban centres are densified and developed at different levels separating pedestrian and vehicle traffic. Industrial areas are dispersed in the city. Cumbernauld, Hook or Thamesmead belong to this stage.

The third would be the result of a synthesis of the first two. Neighbourhood units are used again but developed radially and connected by

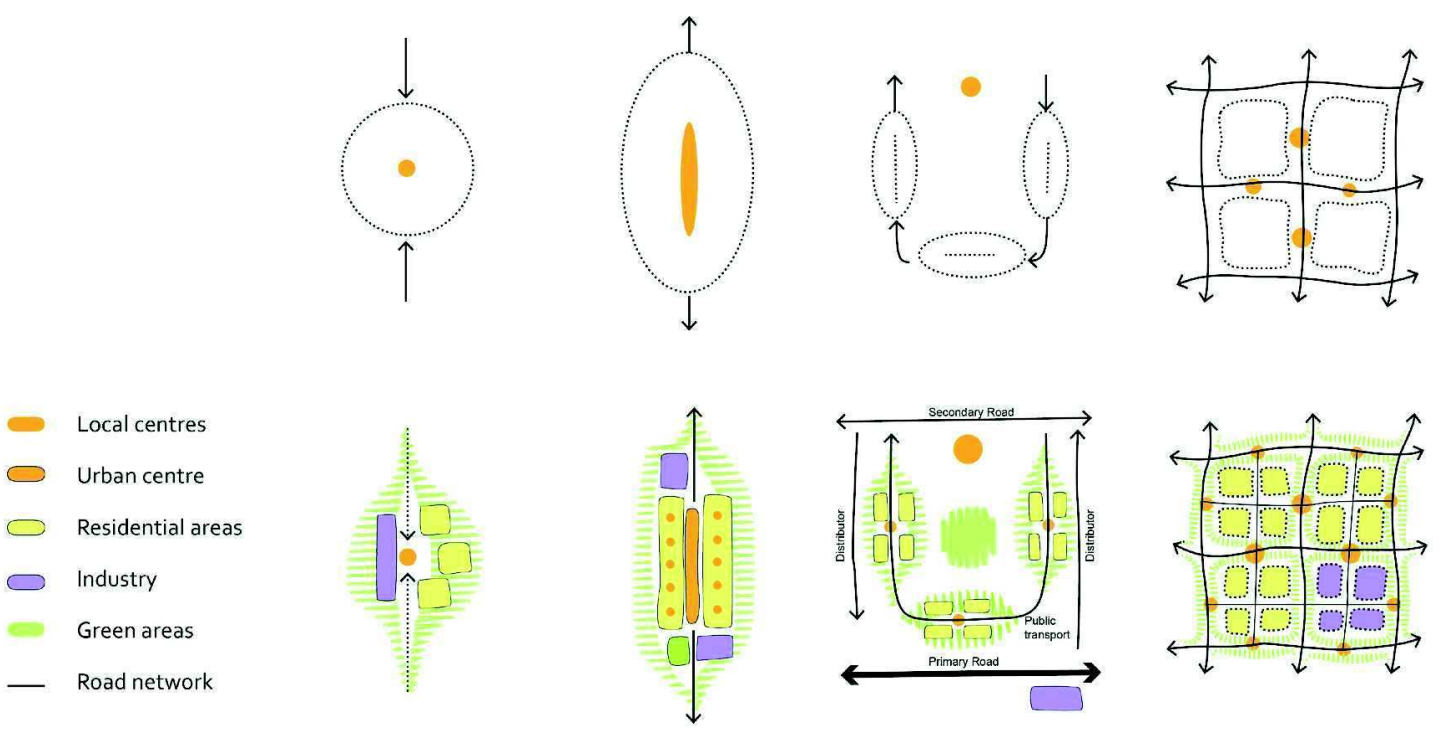

Figure 5.

Schemes of the phases of the development and design of the four phases. Source: redrawn from the schemes which appear in Madani-Pour, (1993). 
means of the public transport network, placing the facilities associated with their stops. With examples like Runcorn.

Finally, the towns of the last phase, seeking a greater flexibility and freedom of choice than their predecessors, due to the increase of mobility and use of the private vehicle, introduce an open road grid where the urban fabric is freely inserted. Local centres are located on the edges of the neighbourhood units. Its most paradigmatic example is Milton Keynes.

\section{Conclusion}

The reflection on the essential characteristics of each of the phases and their analysis, has allowed us to make a diagnosis of the different forms of development, of the advances and setbacks of the British New Towns. We have been able to evaluate comparatively the strategies of mobility and ordering of the uses and their local and territorial relations, the order and composition structures.

The conclusions of the communication recognize the contributions of the New Towns in their different phases, from the different proposals of urban form, and its validity as references of a new urban form in the current context.

For example, one of the recent studies published on the New Towns (TCPA, 2014) states that they have indeed been successful, being among the most advanced and successful communities demonstrating the strength of their plans.

"The New Towns and Garden Cities are among the UK's most successful and progressive communities. [...] The New Town approach has demonstrated the strength of the masterplan, the key role of community development, the role of mass public investment in urbanisation (repaid with interest) and speed of delivery. (TCPA, 2014)"

They have been considered at different moments in their history as successful urban experiences as a whole (DGLC, 2006). In addition to meeting most of the main objectives, they have offered another set of benefits to the communities and their inhabitants, as well as lessons on town planning and architecture.
Territorial and local planning scales

The new towns tried to promote the rational distribution of population flows and activities to implement new territorial equilibriums to avoid the characteristic dysfunctions of large agglomerations. The territory is conceived at a regional and national scale, not only local, and solutions are planned accordingly.

Urban structures and public spaces

A control of the form and distribution of uses faithful to the principles of the urban culture from which they evolve and the moment in which they are designed underlie in the New Towns. The relation systems between the elements of its structure: road, greens, facilities, plots, buildings, free spaces, ensured the legibility of the whole and the achievement of the general interest objectives. Its configuration was materialized through the urban project and the landscape, thus avoiding the disaggregation of the urban space and the aggression on the territory, in opposition of expanding the cities infinitely.

As for the mix of uses, they incorporate areas of centrality which accommodate the collective and productive use spaces in well-communicated locations. Transport networks have been recognized for their good accessibility and for delaying road congestion. (TCPA, 2014)

\section{Town and country relationships}

The New Towns were cities linked to a territory and often participated in the rural world to the extent in which they recognized the existing heritage values and the environmental qualities. They also inherited from the Garden City the respectful movement from the traditional city to the countryside.

Nature and city

New Towns try to maintain and emphasize the natural features and the elements of the landscape that their designated area has, as 
well as integrating them in its green structure as a decisive and determinant factor of the character the city had to assume. In addition to the existing green spaces in the area, new ones of a different scale are created and associated with the city. The artificialization of the urbanized land was compensated with the incorporation of natural elements and green zones, an aspect which was internalized in the projects as a starting point.

One of the greatest achievements of the New Towns (TCPA, 2014) was the creation of generous gardens and public parks where the population could rest and enjoy the direct relationship with nature and the countryside. In general, the proportion of green spaces for collective use to develop joint activities and for outdoor sports is much higher in the New Towns than in other traditional cities with similar populations.

\section{Urbs \& civitas. Communities created}

The new towns intended to cover the basic needs of citizens under their capacity of being both a resident, a consumer of spaces, and a citizen, a member of a self-organizing participatory democracies. The inseparable relationship between the two terms, physical and social, allows to defend certain compromises in the shaping of their projects which tilted the form and the functional and citizen coordination of their districts and neighbourhood units.

\section{Sustainability}

Regarding sustainability, a relatively new concept, the New Towns far from being obsolete, are an example to follow as they meet many of the premises that are required to new urban development's today. The number of green areas and the relationship of landscaped areas with other urban functions, control of population growth, relations of respect for nature and the immediate territory, social balance and equal opportunities, among others, are basic issues in which New Towns have responded to the commitments of sustainable settlements.

One of the fundamental questions in the design and efficiency of the plans for the New
Towns was to put demographic limits, to avoid what happened in the cities from which their settlers came from. Through planning and design, architects and town planners were in charge of improving living conditions and creating the new opportunities that a model settlement could offer to its inhabitants. In both the New Towns and the previous models of the garden city, urban planners and managers went for a rational and unitary urban structure.

Undoubtedly, within the discipline, the New Towns constitute a further step in the search for solutions to the problems that the city of its time posed. In that historical sequence, we have seen the moment in which they arise and how they are inspired and inherit concepts from past experiences such as the Neighbourhood Units, the postulates of the Garden City and the Modern Movement. They take these experiences and reinterpret them in the aspects that they consider more valid, as well as advancing on other issues that in the end will be decisive and, somehow, representative of a way to solve urban demands. As for example, the way they face the conditions of the territory and how to integrate in a landscape, or the functional and compositional relations between the parts which are going to define the urban ensemble.

These contributions applied to different locations and at different times have given rise to very varied solutions: neighbourhoods with garden city typologies or other more compact and with high buildings, sizes and urban forms variations, population, densities, distances to the metropolis or residential unit sizes.

New urban morphologies were tested in the New Towns, incorporating the modifications resulting from the revision and improvement of the model previously used, as well as the alternatives offered by the architecture and urbanism of the time to solve the inherited conflicts. Having relative commitments, in terms of the prevalence of consolidated urban morphologies on which to grow, allowed them to respond with freedom to: the greater rationalization of mobility and transportation systems, the priority of public spaces, equitable and egalitarian distribution of services and facilities, establish healthier environments, modern and better equipped accommodation, 
as well as providing more democratic employment and participation opportunities.
The Lessons of Experience. London: Calouste Gulbenkian Foundation.

\section{References}

ALEXANDER, A. (2009). Britain's New Towns: Garden Cities to Sustainable Communities. Wolverhampton: Routledge .

BURTON, A. y HARTLEY, J. (2003). The New Towns Record 1946-2002 [DVD]. IDOX information centre.

DCLG. Department for Communities and Local Government: (2006). Transferable Lessons from the New Towns.(http:// www.futurecommunities.net/files/images/ Transferable_lessons_from_new_towns_0. pdf.) Accessed: 28 May $201 \overline{7}$.

ENTP (European New Towns \& Pilot Cities Platform). $\quad<$ http://www.pilotcities.eu/> [Consulta: 28 mayo de 2017]

GABORIT, P. (2010). European New Towns: Image, Identities, Future Perspectives. (PIEPeter Lang SA., Brussels)

GIBBERD, F. (1962). Town Design. London: Architectural Press.

HALL, P. (2002). Urban and Regional Planning. 4th ed. London: Routledge.

HMSO. Great Britain. New Towns Committee. (1946 a). Final Report of the New Towns Committee. London

HMSO. Great Britain. New Towns Act. (1946 b). London

INTI (International New Town Institute). $<$ http://www.newtowninstitute.org/> [Consulta: 28 mayo de 2017]

MADANI-POUR, A. (1993). 'Urban Design in the British New Towns'. Open House International, vol. 18.

POTTER, S. and Open University. (1976). "Transport and New Towns". New Towns Study Unit. Milton Keynes: Open University.

TCPA. (2014). New Towns and Garden Cities - Lessons for Tomorrow. Stage 1: An Introduction to the UK's New Towns and Garden Cities. (Town and Country Planning Association, London) Accessed: 28 May 2017. (https://www.tcpa.org.uk/Handlers/ Download.ashx? IDMF=1bcdbbe3-f4c949b4-892e-2d85b5be6b87).

WARD, C. (1993). New Town, Home Town: 